\title{
In the gestuality of teachers and babies, the body talks of relationships
}

\author{
BONFIM, Patrícia Vieira (Niterói, Rio de Janeiro, Brasil) ${ }^{1 *}$ \\ OSTETTO, Luciana Esmeralda (Niterói, Rio de Janeiro, Brasil) $)^{2 *}$ \\ ${ }^{1}$ Universidade Federal Fluminense, Programa de Pós-Graduação em Educação, \\ Doutorado em Educação \\ ${ }^{2}$ Universidade Federal Fluminense, Programa de Pós-Graduação em Educação, \\ Faculdade de Educação \\ ORCID ID: http://orcid.org/0000-0002-6989-7034* \\ ORCID ID: https://orcid.org/0000-0002-1948-5090*
}

\begin{abstract}
With the body, the individual suspects the world, affects and is affected by it, builds relationships, signifies and expresses existence. What do the bodies of babies and adults say about each other? Based mainly on Wallonian Psychology and Lebretonian Anthropology, this article presents partial results of a doctoral research that aims to analyze narratives about/with the body woven in the interactions between teachers and babies. The data, resulting from the observation of a group of babies with their teachers, were generated through written and photographic records, focusing on different moments of the routine, later appreciated and discussed in meetings with the teachers. For the analysis presented here, relational movements composed by the gestures produced between babies and teachers were observed in the environment outside the reference room. It was preliminarily noted that the quality of the relationship established between them was fundamental to activate the discovery of the body, in the experimentation of space, textures, shapes and flavors.
\end{abstract}

\section{Keywords}

Body. Early Childhood Education. Daycare. Adult-baby relationships.

\section{Na gestualidade de professoras e bebês, o corpo fala de relações}

\begin{abstract}
Resumo
Com o corpo, o indivíduo suspeita o mundo, afeta e é por ele afetado, constrói relações, significa e expressa a existência. O que dizem os corpos de bebês e de adultos em relação? Referenciado sobretudo na Psicologia walloniana e na Antropologia lebretoniana, apresentam-se resultados parciais de pesquisa de doutorado que objetiva analisar narrativas sobre/com o corpo tecidas nas interações entre professoras e bebês. Os dados, advindos da observação de um grupo de bebês com suas professoras, foram gerados mediante registros escritos e fotográficos, focando diferentes momentos da rotina, posteriormente apreciados e discutidos em encontros com as docentes. Para a análise, observaram-se movimentos relacionais compostos por gestos produzidos entre bebês e professoras no ambiente externo à sala de referência. Notou-se preliminarmente que a qualidade da relação estabelecida entre eles foi fundamental para ativar a descoberta do corpo, na experimentação do espaço, das texturas, das formas e dos sabores.
\end{abstract}

\section{Palavras-chave}

Corpo. Educação infantil. Creche. Interações adulto-bebês.

1 The research has financial resources from the Support Program for the Qualification of Servers (Proaq) of the Federal Institute of Education, Science and Technology (IF) Southeast of Minas Gerais, Muriaé campus (Edital no 18/2017). 


\title{
Gestos dibujados entre bebés y maestros en la educación de la primera
}

\author{
infancia: aprendizaje corporal ampliado
}

\begin{abstract}
Resumen
Con el cuerpo, el individuo sospecha del mundo, lo afecta y se ve afectado por él, construye relaciones, significa y expresa la existencia. ¿Qué dicen los cuerpos de bebés y adultos el uno del otro? Referenciado principalmente en la Psicología walloniana y la Antropología lebretoniana, este artículo presenta resultados parciales de una investigación doctoral que tiene como objetivo analizar narraciones sobre / con el cuerpo tejidas en las interacciones entre maestros y bebés. Los datos resultantes de la observación de un grupo de bebés con sus maestros se generaron a través de registros escritos y fotográficos, enfocándose en diferentes momentos de la rutina, luego apreciados y discutidos en reuniones con los maestros. Para el análisis presentado aquí, los movimientos relacionales compuestos por los gestos producidos entre los bebés y los maestros se observaron en el entorno fuera de la sala de referencia. Se observó preliminarmente que la calidad de la relación establecida entre ellos era fundamental para activar el descubrimiento del cuerpo en la experimentación de espacios, texturas, formas y sabores.
\end{abstract}

\section{Palabras clave}

Cuerpo. Educación infantil. Guarderías. Interacciones adulto-bebés.

\section{Introduction}

Nowadays, the departure of babies from the family environment to frequent spaces dedicated to care and education, such as daycares, is increasingly noteworthy. This is especially due to the intensification of the urbanization process, the acknowledgment of Early Childhood Education advantages for children and the growing participation of Brazilian women in the workforce (CAMARANO; KANSO; ALCÂNTRA, 2014). Although there are multiple reasons for babies to frequent daycares, it is certain that education is a right granted to children in the Brazilian Federal Constitution of 1988, restated in the Law of Directions and Bases of National Education from 1996.

However, "[...] the lower the population income is, the lower the rates of children enrolled in daycare and preschools get, which reveals an evasion of that right exactly from those children and families that most need the service" (CAMPOS; CRUZ, 2006, p. 13, our translation). In addition to that observation, we must also note the quality of education offered, especially that offered to babies, considering that 
these are very powerful beings regarding learning, but, at the same time, they are physically fragile before mistaken or negligent educational proposals.

In the research we are developing, we aim to analyze narratives about/with the body woven in the interactions between teachers and babies in the routine of a public daycare in Minas Gerais. This proposal gives visibility to interactions, one of the axes that should be considered in the pedagogical practice developed by institutions of Early Childhood Education (BRASIL, 2009). In this sense, it also envisions the quality of education for children between 0 and 3 years of age, as far as those interactions reveal concepts, prejudices, limits and possibilities of the bodies.

The body, main element of this study, is approached in its entirety (affectivity, motor action, intelligence and construction of the individual) (WALLON, 1975, 2007); endowed with esthesia; capable, thus, of perceiving the surrounding world through senses - touch, taste, hearing, vision and smell (LE BRETON, 2012b, 2016; NÓBREGA, 2008). The body also possesses communicative and expressive language, defined in the context of a given culture and society (LE BRETON, 2012a, 2019).

According to Le Breton (2012b), the places where one lives interfere directly on the processes of human sociability and perception of the body. If the size of western houses, the disposition of materials in space, objects and landscapes give hints of human relationships that are nurtured or not, it is no less important to consider how the bodies express themselves or are repressed in the first years of school education.

Based on those theoretical premises, the problem question that motivates the investigation can be thus expressed: which narratives about/with the body are woven in daycare considering the interactions between adults and babies? Aiming to advance that discussion in this article, we organized it as follows: in a first moment, we present the theoretical premises that base our concept of body, proposing a dialogue between two French authors: Henri Wallon (1879-1962), an important philosopher, doctor and psychologist, and David Le Breton, anthropologist, sociologist and writer. In a second moment, we present the methodological path and the concepts that ground our understanding regarding qualitative research in Education. In a third moment, we approach some data produced in this journey. Considering that this research is ongoing, in the fourth and final moment of the text, 
we point to preliminary results and highlight the first contributions of the study for the field of Early Childhood Education, especially for the education of children between the ages of 0 and 3 in daycares.

\title{
2 The (em)bodied world in relationships
}

\begin{abstract}
Through the senses, we suspect the world. With the eyes, we look at life. [...] Looking is fantasizing about what is hidden behind things. When we look, we awaken joy, sadness, yearning, love, memories, which sleep in our hearts. The eyes have roots all through the body. (QUEIRÓS, 2009, p. 6-9, our translation).
\end{abstract}

The poet from Minas Gerais, in his book Os cinco sentidos (The five senses), makes us reflect that we understand the world perceptively. He states that this understanding, through vision, hearing, smell, taste and touch, has deep and broad roots, which involve the entire body. Therefore, when we look at a landscape, for example, it can bring up memories of faraway places, the voice of a loved one, smell and tastes from childhood. As Le Breton (2009) says, the reminiscences of/in the body can flourish from a free association that gives life to a story from the past.

Poets and scientists indicate: in each sense, there are other senses, which awaken fantasies and cause dreams. Through the senses, we capture and signify the world, becoming expanded bodies, repressed bodies, fragilized bodies, active bodies. Based on this point and as announced in the introduction of the text, to situate the perspective through which we understand the body, we rely on an interdisciplinary approach that contemplates two French researchers with broad training: Henri Wallon and David Le Breton.

Wallon (2007) discusses, in his theories, that human beings, since early childhood, are whole people. This can be noticed in his concept of psychogenesis of the complete person, which encompasses, in an integrated way, the processes that constitute the human psyche: affectivity, the motor action (movement), knowledge (or intelligence) and the construction of the individual (or construction of self).

To the aforementioned author, affectivity is human beings' capability, from an early age, to be affected, whether by the internal or external world. Affectivity encompasses emotion, feelings and passion, with emotion as the most visible manifestation of affectivity. 
This is how, for example, the human baby, since its first days of life, connects to the Other and communicates through babbling, crying and disordered movements of hands and feet (WALLON, 2007).

In order to expand our vision of emotions, Le Breton $(2009,2019)$ emphasizes that they shouldn't be studied as physiological or psychological phenomena in an isolated way, although these aspects are also important for their understanding. With Anthropology's input, emotions are seen as a cultural and social construct; therefore, situations such as the birth of a child, experiencing grief or failing an exam can vary depending on the group that experiences it.

Whereas Le Breton $(2009,2019)$ doesn't consider the concepts of emotion and feeling separately, Wallon (2007) does so, highlighting that if, on one hand, emotions emerge, on the other hand, feelings are less noticeable; thus, they are restricted to the cognitive realm. This explains why young children tend not to be able to handle the sentimental psychic processes that are in the elaboration phase. Consequently:

\begin{abstract}
Children prompted by feeling don't have, regarding the circumstances, the instantaneous and direct reactions of emotion. Their attitude is of abstention, and, if they observe, it is like a distant and furtive look that rejects any active participation in the relationships formed around them. Trying to provoke them is putting them in a bad mood; they become grumpy for lack of aptitude and taste for improvised exchanges with the other. They seem to close in on themselves the circuit of their impressions; often absorbed by sucking their thumb, they ruminate internally. This initial stage, defensive and negative, can only change with the appearance and progress of mental representations that will provide their daydreams with reasons and themes more or less bygone. (WALLON, 2007, p. 126 , our translation).
\end{abstract}

This explanation contributes to think about babies and toddlers in Early Childhood Education, because understanding how feelings are structured and reading body language in a sensitive and attentive way are attitudes that can facilitate the interpretation of apathy, which is sometimes mistakenly interpreted by the school as a child's lack of interest in an activity.

Considering that the body isn't only an affective set, but a unit that must be experienced in the elaboration of the child's processes of development and learning, this unit also encompasses the motor system. In other words, the set that enables the many methods of movement: 
1. movements of the body in time and space, according to the laws of gravity; 2 . voluntary or intentional movements of the body or of parts of it; 3. postural reactions that are characterized by mimicry and facial expressions when faced with different situations. (ALMEIDA, 2014, p. 597, our translation).

Human movement begins during fetal life, when, approximately after four months, the pregnant person can feel the first active movements of the baby in the womb. After birth, the baby makes spontaneous gestures, which will support their thoughts and, throughout time, become more conscious and coordinated. Reflecting about interactions in the processes that set off human movement in each culture, Le Breton (2012a, p. 44, our translation) emphasizes that gestuality:

[...] refers to the actions of the body when the actors meet: greeting or parting ritual (hand sign, nodding, handshake, hugs, kisses on the face or lips, mimicry etc.), consenting or denying methods, movements of the face and body that accompany the emission of words, direction of the eyes, variation in the distance separating the actors, methods of touching or of avoiding contact etc.

Therefore, we still have a lot to advance in studies focusing on the bodies of babies and adults during interactions, since there are meaningful and asymmetrical differences that mark the gestuality of those two intergenerational groups. According to Wallon (2007), children think through movement. Thus, this action shouldn't be seen as indiscipline, but as indispensable to child development and the cognitive set that the author calls knowledge or intelligence. According to him, the purpose of intelligence resides in two aspects: defining and explaining, and is inextricably linked to the affective and motor sets.

From a perspective that expands this view of perceiving human beings as an indivisible whole, Le Breton (2009, p. 112, our translation) clarifies and explains his position:

Opposing 'reason' and 'emotion' would be ignoring that both are inscribed in the core of personal logics, permeated by values and, therefore, affectivity. There is an intelligibility of emotion, a logic that is imposed to it; likewise, there is affectivity in the most rigorous thought, an emotion that conditions it.

This theoretical framework has allowed us to interpret the images of bodies of babies and adults as complete beings, in their affective, motor and cognitive aspects, as did Wallon (2007) in his fourth and last functioning set, which he named "The Person". 


\section{Under methodological crosshairs: observations, written and photographic records, meetings and narratives}

Based on the objective listed, analyzing narratives about/with the body, woven in interactions between teachers and babies in the routine of a public daycare, we chose to carry out a qualitative research, which, according to Lüdke and André (2013), leads to a direct and more prolonged relationship between the researcher and the environment and subjects studied, more intense through exhausting field work. We chose this type of research also because we consider it the most adequate regarding the following aspects:

The process is more meaningful than the product. The researcher's interest in studying a certain problem is in verifying how it manifests in activities, procedures and routine interactions. [...] The 'meaning' that people confer to things and their lives are the focus of special attention to the researcher. There is always an attempt to capture the 'perspective of the participants', i.e., how contributors face the issues in focus. (LÜDKE; ANDRÉ, 2013, p. 11-13, our translation).

All these characteristics of qualitative research generate an intense reflective exercise around the reality studied and concurrently require openness and flexibility from the researchers to handle situations that are beyond what was planned, predictable. Aware of limits and potential of this approach, the clarity we have is to carry out a research with babies and educators in the school routine, and not just a research that has them in the background.

That said, the field research took place at an Early Childhood Education Center in Ipatinga, a city in the eastern region of Minas Gerais, nationally renowned for hosting one of the units of the steel mill Usina Intendente Câmara (Usiminas). According to data from the Brazilian Institute of Geography and Statistics (IBGE, 2018), in 2017, Ipatinga had a population of approximately 261,203 people. According to the Municipal Secretariat of Education of that city, in 2018, 906 children were enrolled in ten municipal public daycares and 2,575 children were enrolled in 34 public daycares of the associated network. 
This Early Childhood Education Center is a municipal public daycare, located downtown, which serves children up to three years of age. In 2018, the year when the field research took place, there was a group of babies (ten boys and four girls) who were between 13 and 20 months old during the observation.

Regarding the four professionals who worked with those babies, two were regent teachers and two were teaching assistants in Early Childhood Education, with a 40-hour weekly workload directly with the babies. Only one of the professionals had tenure. The others were hired through a selection process. Concerning training, two attended Normal School for Elementary School Teaching and were enrolled in a Pedagogy undergraduate course, and two had graduated from undergraduate and lato sensu graduate school. It should be emphasized that all four teachers in the investigated nursery accepted to participate in the research, a criterium that contributed to the choice of daycare.

With their acceptance and formal authorizations by school management, the teachers and the babies' guardians, we started the observation of the nursery routine, which lasted about three weeks. To record observations, we relied on two resources: the field notebook, which helped in the description and interpretation of some scenes; and the smartphone, with which we took photographs.

The sequences of images produced focused on points of corporal contact between teachers and babies. As for the framing of the pictures, we used two types of shots: "narrative", in order to capture two or more people interacting; and "expressive", in order to focus even more on what we wanted to record, such as expressions and gestures (ROSATELLI; SPINOLA; MAZZOCO, 2014).

In addition to technical precautions, we were careful not to turn the photographs into a mere reproduction of what has been happening in our postmodern society, in which living the present - the here and now - seem less significant than the image. Recording everyday scenes through photographs was a rich element for the research: the photograph capturing past scenes, times, spaces and events enables, when revisited, the activation of memory and remembrance. According to Rosatelli (2016, p. 7 , our translation): 
[...] the photographical act is a cognitive, creative and affective act - all at the same time -, with the rare ability to transform, both symbolically and physically, this space. Photographer Henri Cartier-Bresson reinforces this meaning of seeing in his iconic sentence: 'It is putting one's head, one's eye, and one's heart on the same axis'.

Understanding photographs in this research as a visual memory and an artistic language, we sought to adjust our internal perception to the outside camera, in order to capture, in the teaching routine, not only the beauty unveiled in the art of the encounter between babies and teachers, but the noises and shortages, inserting what was captured in a context and being careful not to isolate the content.

The images produced served as mediation for the meetings (recorded in audio and transcribed) that took place on scheduled dates with each teacher, individually, after the observation. For the meetings, the images were organized into Episodes (consisting of four sequential photographs) and projected through PowerPoint on the laptop of one of the researchers.

Image selection had the participation of one researcher and the teachers that participated in the research. Concurrently to the observation in the nursery, we organized the files, choosing the Episodes that best fit the purposes of the research. In this process, we disregarded photographs that were blurry and/or unfocused. At a later time and individually with each educator, we provided a folder with images corresponding to the records of interaction between the professional and the babies and suggested that they choose some scenes that would be appreciated and discussed during the meetings. Underneath the proposal, a confirmation: talking about bodies is necessary in daycare.

\section{Vestiges of the bodies in the type of approximate relational movements}

Narrative meetings, as an investigation methodology, are presented as tools that evade the traditional interview models, based on a standard script, supported by the dynamics of questions and answers (SOUSA; CABRAL, 2015). Our script was designed by the choice of photographic records produced during observations. Thus, the oral narratives were mobilized by photographs of the teachers' pedagogical practices, which 
seemed to generate great interest in them, not only to share their experiences, but also to explain their intentions and desires, accomplished or not.

Obeying the limits of length for the present text, two photograph sequences and their corresponding records in the field notebook will be presented and discussed. We also present the transcription from the oral narrative of one teacher who participated in the study. In this case, the excerpted data included two moments when the adult and baby bodies were outside, in contact with nature, in the context of the daycare park.

\subsection{Episode 1: Experiencing textures and colors in nature}

Figure 1 - Episode 1: Teacher Michelly with the babies Gabriel, Davi Correa, Davi Silva, Pedro, Miguel,
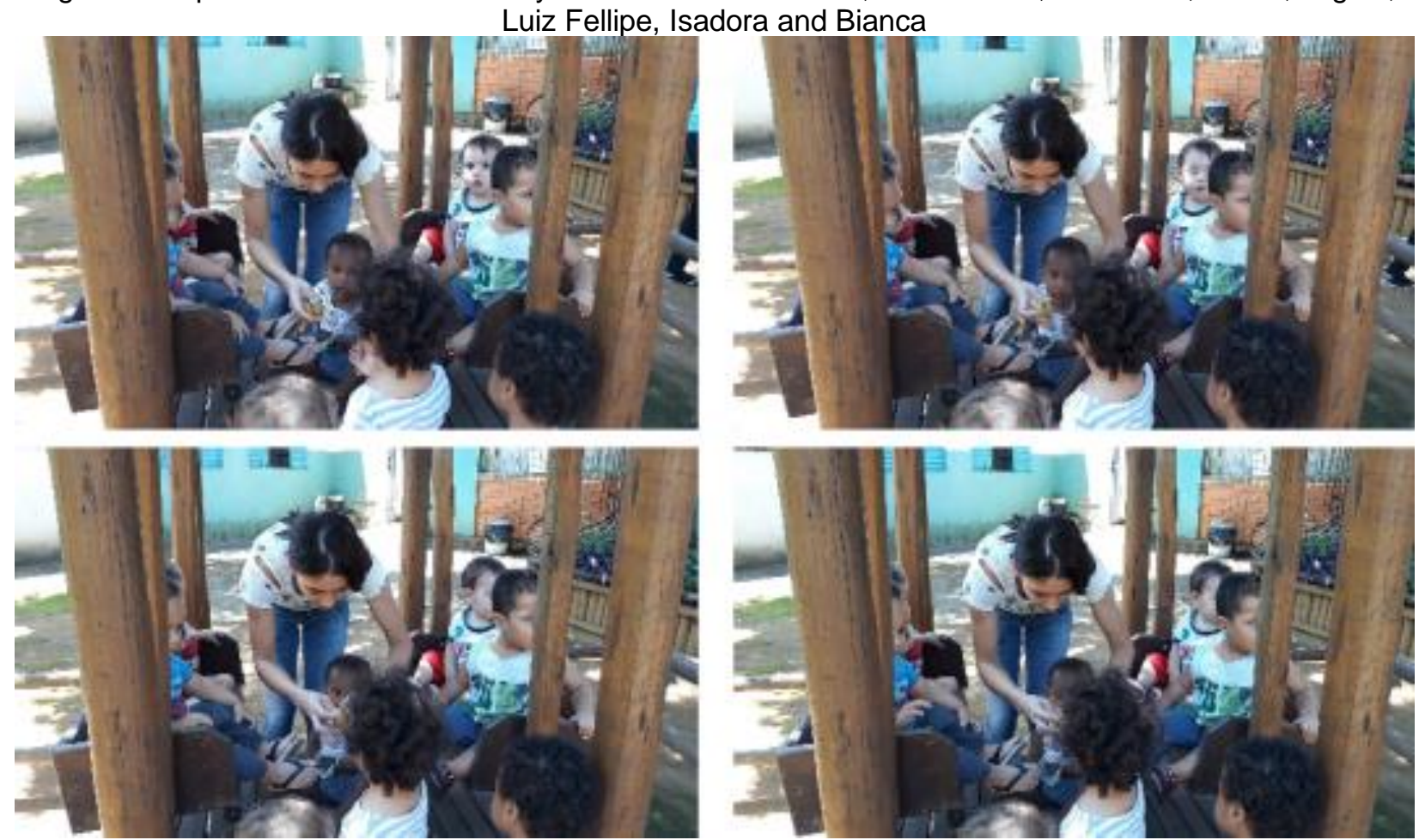

Source: Research archive. Field record, 11/26/2018.

We entered the daycare space-time and had access to several spaces, one of which, located outside the group's reference room, seemed to delight the babies and teachers: the park. This space was in the daycare's backyard and enabled contact with nature; it had stationary and mobile toys, a lot of sand and trees that provided shade. In addition to demonstrations of appreciation by the babies, perhaps for enabling greater movement range and diverse play, we verified that this space relieved the teachers' routine, which was often limited within four walls.

Educação \& Formação, Fortaleza, v. 5, n. 14, p. 115-132, maio/ago. 2020

DOI: https://doi.org/10.25053/redufor.v5i14mai/ago.1647in

http://seer.uece.br/redufor 
The teacher announced that they would go to the daycare park. Some started to take off their shoes quickly, others laughed, and two girls walked and positioned themselves by the classroom door to wait. Teacher Michelly took a deep breath. She seemed relieved. Usually she was the one who bathed most of the babies, who changed diapers (around 70 per day, approximately five for each baby). Her routine was almost always in the baby-changing area, a room with little ventilation behind the nursery. Michelly's job, teaching assistant, didn't provide planning moments, like the regent teachers had. Arriving at the park, Michelly sat with two babies on a swing. She made movements with her body to swing. Little by little, other children approached the swing. She stood up so that they could sit down. She swung them. Some looked and smiled at her. Michelly returned their smile. At that moment, Bianca approaches, a 16month-old baby who entered the scene and my focus, but who had clearly been noticed by the teacher. She brings in her little hands a mango that she found on the ground. She communicates, through gestures, what she found. Then, she gets the attention of two other babies who come closer and of those who are already on the swing. She gives the fruit to the teacher, who receives it, presses it, says it's tough, that it can't be eaten, gives it to the other babies so that they can feel the texture too. Gabriel repeats: 'It's tough'. Bianca goes back to the tree, picks up some leaves, touches the sand, puts a hand next to her ear, as if she was trying to hear a singing bird better. She looks up, observes. Looks down, looks for another fruit on the ground. When she finds it, she picks it up, smells it, brings it to her mouth. The teacher follows her with her eyes. In this moment, she goes back to Michelly holding the fruit. (Observation record. Field notebook. 11/26/2018. Our translation).

The "following with the eyes", gestuality observed between adult and baby in the scene described, contributes to understand what Le Breton (2009) highlights about inquiring with the eyes as the distance in established communicability relations increases. It is as if this attitude supplied a corporal absence between the individuals and, at the same time, enabled the previously started dialogue to continue.

Bianca's movements and gestures allowed the teacher to decipher the child's desires and subsequently perceive her own body, which rarely seemed to express itself freely, considering the automatized movements of her routine, such as changing several diapers every day, bending down and getting up to clean the babies.

Studies indicate that body language potentially acts in interpersonal relationships, mediating the rational, motor and affective aspects, expanding, thus, sensitivity (OLIVEIRA, 2014). This language, when experienced in school education, may not only favor the babies' processes of development and learning, but also human development more broadly. In the photographic sequence generated, regarding Episode 1, and in corresponding records, we can identify signs of learning and of development processes: the bodies meet, dialogue and produce meanings, mediated by language activated by body gestures.

Educação \& Formação, Fortaleza, v. 5, n. 14, p. 115-132, maio/ago. 2020 
A pronounced gesture brings in itself and announces other gestures, because the body carried many stories, and, "[...] in the immediate gesture, we see, there they are, other gestures enveloping the present, determined by past gestures, which anteceded it, and, in the now, indicate and refer a succession of other gestures" (OSTETTO, 2012, p. 126, our translation). This was verified in the teacher's narrative during the meeting:

\begin{abstract}
We were there in the park and we were all on the swing. Bianca wasn't sitting down, she was somewhere else. The interesting thing is that she picked up that object from the ground. She didn't know what it was and came to me to give me it. She was looking at me to try to identify what it was, for me to tell her what it was. Then I told her it was a mango, but we couldn't eat it, it wasn't mature, still tough! I let them [the babies] touch it, see the texture, hold, press it, see it was tough, that we couldn't eat it. And I explained to her: 'It's yellow, but it's yellow from the Sun, because of the Sun, it can't be eaten; it fell from the tree, but can't be eaten'. Then she saw, identified that one couldn't be eaten and went to look for another. She found another one, brought it to me again. I showed them again that this one also couldn't be eaten. Then, I realized what she was trying to do, it wasn't just identify that object, but she already knew that object and wanted to eat (in this case, the mango), then, I searched, tried to find somewhere if there were any mangoes good to eat. (Recording of the meeting on 11/28/2018. Narratives by teacher Michelly about Episode 1. Our translation).
\end{abstract}

Michelly's narratives confirm that, through her careful observation of the expressions, gestures and body movements of a baby (who, exploring her surroundings, seeks an element of nature that interests her), her corporal action is also expanded and mobilized for other movements, resulting in inviting her Self and Other bodies to see the park, feel the nature, to experience textures and shapes.

We identify an esthesic relation, because we understand esthesia as "[...] communication marked by the senses that sensoriality and historicity create, in an always temporary synthesis, in existential dialectics that move one human body toward another" (NÓBREGA, 2008, p. 147, our translation). Through the movements of looking, interacting and welcoming Bianca's gestures, Michelly seeks to decode the child's interests, perceiving the body in its entirety (WALLON, 2007). Therefore, she interprets what the baby, without words, says and searches for a mature fruit. 


\subsection{Episode 2: Flavors of nature}

Figure 2 - Episode 2: Teacher Michelly with the babies Luiz Fellipe, Bianca, Laura and Lara
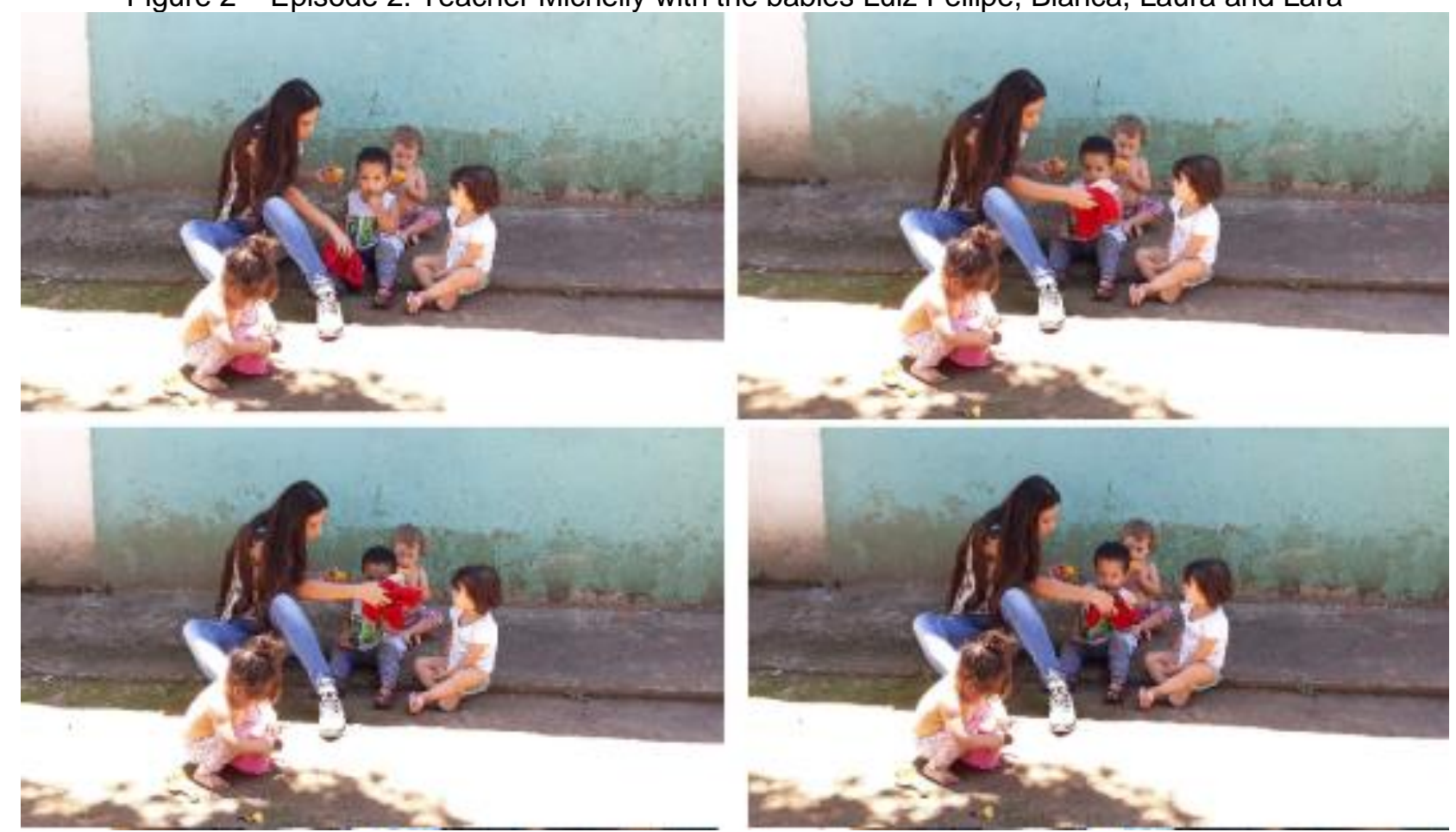

Source: Research archive. Field record, 11/26/2018.

With the mouth we feel the taste of things: sweet, bitter, sour, mild, strong. But flavor awakens our memory. The taste of milk caramel brings the memory of the mother at the stove and we even hear the spoon scratching the bottom of the pan. Flavor shortens time. We discover that each taste has a history. [...] The mouth has roots all through the body. (QUEIRÓS, 2009, p. 9-10, our translation).

Returning to the poet from Minas Gerais, he is still right! Literature invites us to reflect that flavors, smells, touch and sound push the body toward movement, transposes it from the present to the past and from the past to the present with sudden speed, allowing the human being that inhabits us to meet their completeness again. In the analysis of the body language carried out in the succession of photographic sequences, we realize that the teacher's action was indispensable in both episodes, because it was Michelly who welcomed Bianca through her eyes, her words, the value she gave to the subtleties found on the ground by the girl, seeking in the child's dialogue with nature new body gestualities (PIORSKI, 2016), as we can notice in her own words: 
This [photo sequence] is the moment when she [the baby] found the mango, but it wasn't the right mango to eat. And I noticed that she wanted to find one to eat. That's why she was searching. So, I searched, identified it, managed to find a mango that she could eat. So, I peeled it, showed her, went and washed her hands, because they were at the park, they were playing with sand. I cleaned her hand and gave her the mango. I thought it was funny, because she held the mango properly, with both hands, and brought it to her mouth. So, through that, I understood that she already knows it. Someone at home must have showed her something like that, and she identified that this object she could eat, that this fruit she can eat, that it's a mango. And the funny thing is that she was alone. I got it, brought her, and left her alone. That she was the only one who identified that she could eat that. And the others didn't. For them, it was only an object, they don't know what it is; they can't identify. Then, since they saw she was eating, they came closer, even to discover, see the texture, taste it. So, they got close and I let them hold it too to notice, learn. (Recording of the meeting on 11/28/2018. Narratives by teacher Michelly about Episode 2. Our translation).

During the corporal narratives between Bianca and the teacher, Luiz Fellipe, the same baby who was present in Episode 1 with the girl, seems to be interested in the fruit, follows the teacher with his eyes, goes to her and tries to express that he also wants to taste the mango. It is interesting to notice, without attributing value judgment, the marks of western culture, of the hygienist view, for example, in the teacher's concern to wash the baby's hands before eating the mango. We also notice a characteristic way to hold the fruit, that the teacher refers to as "properly". This corroborates what Le Breton (2012a, p. 8, our translation) affirms: "The child's actions and gestures are involved by the cultural standard (ethos) that elicits the forms of their sensibility, gestuality, the perceptive activities, and thus designs the style of their relationship with the world". In summary, we noticed that the baby Bianca caused the gestuality of the teacher and of other classmates, becoming the protagonist of rich and challenging experiences at daycare.

\section{In nature, possibilities of expanded corporal relations}

Just as in the two basic breathing movements - inspiration and expiration -, in the spaces and times of daycare, the corporal movements of adults and babies interacting expand and contract. What we observed in the types of approximate relational movements, present in the episodes recorded outside, is that the quality of the relationship established between teacher and babies was paramount to the discovery of

Educação \& Formação, Fortaleza, v. 5, n. 14, p. 115-132, maio/ago. 2020

DOI: https://doi.org/10.25053/redufor.v5i14mai/ago.1647in

http://seer.uece.br/redufor 
the body in experimenting the space, textures, shapes and flavor, and also to understand gestures as language.

No less important to consider is that nature may enable, to those who enjoy it, more intense and vibrant experiences and perceptions of the body, which could be noticed in movements such as looking at the sky and the ground, listening to the bird, picking up the leaf, touching the sand, sitting down, collecting, welcoming and sharing. Wouldn't these be rich learning processes at school?

Returning to the initial research question - "Which narratives about/with the body are woven at a nursery considering the interactions between adults and babies in the educational routine?" -, we conclude, although temporarily, that the approximate relation established between teacher and babies in the space-times of the park was welcoming, spontaneous and expressive, visible in gestures, looks, in the interpretation of body language.

An attentive look toward body language in this research brings contributions to think about practices in Early Childhood Education, especially educational practices for children between the ages of 0 and 3 in daycares. First, and paraphrasing Le Breton (2012b), places of education interfere directly in the processes of human sociability and body perception. Second, babies, in contact with nature, provoke in adults the interest in the subtleties, in thinking about other forms of education and temporalities that favor the experience of all senses, of the entire body. Third and lastly, an alert perception of body language helps teachers to look at themselves, a movement that, for our days, is paramount, because: "The everyday flow, with its habitual scansions, tends to hide the game of the body in the sensorial understanding of the world environment or in the actions carried out by the individual" (LE BRETON, 2012b, p. 156, our translation).

\section{References}

ALMEIDA, L. R. A questão do Eu e o Outro na psicogenética walloniana. Estudos de Psicologia, Campinas, v. 21, n. 4, p. 595-604, 2014.

BRASIL. Constituição de 1988. Constituição da República Federativa do Brasil. Diário Oficial [da] República Federativa do Brasil, Poder Executivo, Brasília, DF, 5 out. 1988. 
BRASIL. Lei o 9.394, de 20 de dezembro de 1996. Estabelece as Diretrizes e Bases da Educação Nacional. Diário Oficial [da] República Federativa do Brasil, Poder Executivo, Brasília, DF, 21 dez. 1996.

BRASIL. Resolução CNE/CEB no 5, de 17 de dezembro de 2009. Fixa as Diretrizes Curriculares Nacionais para a Educação Infantil. Diário Oficial [da] República Federativa do Brasil, Poder Executivo, Brasília, DF, 18 abr. 2009.

CAMARANO, A. A.; KANSO, S.; ALCÂNTRA, V. S. Desigualdades na dinâmica demográfica e as suas implicações na distribuição de renda no Brasil. In: CAMARANO, A. A. (Org.). Novo regime demográfico: uma nova relação entre população e desenvolvimento?. Rio de Janeiro: IPEA, 2014. p. 241-270.

CAMPOS, M. M. M.; CRUZ, S. H. Consulta sobre qualidade da educação infantil: o que pensam e querem os sujeitos deste direito. São Paulo: Cortez, 2006.

IBGE - Instituto Brasileiro de Geografia e Estatística. Dados de Ipatinga. Rio de Janeiro: IBGE, 2018.

LE BRETON, D. A sociologia do corpo. 6. ed. Petrópolis: Vozes, 2012a.

LE BRETON, D. Antropologia das emoções. Petrópolis: Vozes, 2019.

LE BRETON, D. Antropologia do corpo e modernidade. 2. ed. Petrópolis: Vozes, 2012b.

LE BRETON, D. Antropologia dos sentidos. Petrópolis: Vozes, 2016.

LE BRETON, D. As paixões ordinárias: antropologia das emoções. Petrópolis: Vozes, 2009.

LÜDKE, M.; ANDRÉ, M. E. D. A. Pesquisa em educação: abordagens qualitativas. 2. ed. São Paulo: EPU, 2013.

NÓBREGA, T. P. Corpo, percepção e conhecimento em Merleau-Ponty. Estudos de Psicologia, Natal, v. 13, p. 141-148, $2008 . \quad$ Available at: http://www.scielo.br/scielo.php?script=sci_arttext\&pid=s1413-294x2008000200006. Access on: Mar. 20, 2020.

OLIVEIRA, N. R. C. Infância, corpo e movimento: notas para (re)pensar os tempos e espaços na educação infantil. In: OLIVEIRA, W. C.; DAMIANO, G. A.; PEREIRA, L. H. P. (Org.). Corporeidade, educação e tecnologias: experiências, possibilidades e desafios. Jundiaí: Paco, 2014. p. 106-120.

OSTETTO, L. E. Dos gestos na educação infantil: textos no corpo. In: OSTETTO, L. E.; LEITE, M. I. (Org.). Arte, infância e formação de professores. 7. ed. Campinas: Papirus, 2012. p. 121-128. 
PIORSKI, G. Brinquedos do chão: a natureza, o imaginário e o brincar. São Paulo: Peirópolis, 2016.

QUEIRÓS, B. C. Os cinco sentidos. 3. ed. São Paulo: Global, 2009.

ROSATELLI, L. A. C. Prefácio: o olhar seguro x o olhar experimental. In: GRUPO MARISTA, Rede de Solidariedade (Org.). Territoriar: relatório de percurso formativo: registro fotográfico. Curitiba: Champagnat, 2016. p. 6-7.

ROSATELLI, L. A. C.; SPINOLA, A.; MAZZOCO, B. Como fazer registro pedagógico em foto e vídeo. 2014. Available at: https://novaescola.org.br/conteudo/1882/registros-quefazem-o-professor-refletir-sobre-a-pratica. Access on: Feb. 5, 2018.

SOUSA, M. G. S.; CABRAL, C. L. A narrativa como opção metodológica de pesquisa e formação de professores. Revista Horizontes, Itatiba, v. 33, p. 149-158, 2015. Available at: https://revistahorizontes.usf.edu.br/horizontes/article/view/149. Access on: Mar. 20, 2020.

WALLON, H. A evolução psicológica da criança. São Paulo: Martins Fontes, 2007.

WALLON, H. Psicologia e educação da infância. Lisboa: Estampa, 1975.

\section{Patrícia Vieira Bonfim (Niterói, Rio de Janeiro, Brasil)} Universidade Federal Fluminense (UFF)

PhD student in Education at UFF. Pedagogue at the Federal Institute of Education, Science and Technology of the Southeast of Minas Gerais - Muriaé campus. Member of the Study and Research Circle Teacher Training, Childhood and Art (FIAR).

Authorship contribution: Production of data (photographic records, audio recording, transcription and notes in a field notebook), preliminary organization of the theoretical framework, delimitation of the analysis category taken to focus on the article and preparation of the initial version of the text.

Lattes: http://lattes.cnpq.br/0490029520812954.

E-mail: patricia.ftbp@gmail.com.

\section{Luciana Esmeralda Ostetto (Niterói, Rio de Janeiro, Brasil) \\ Universidade Federal Fluminense (UFF), Programa de Pós-Graduação em Educação, Faculdade de Educação}

$\mathrm{PhD}$ (2006) in Education from the State University of Campinas (Unicamp) and master (1992) in Education from the Federal University of São Carlos (UFSCar). She is a professor at the Faculty of Education at UFF, where she works in post-graduation (master's and doctorate in Education) and in undergraduate (Pedagogy course).

Authorship contribution: Guidance on research methodology, collaboration in data analysis and content review, with a proposal for theoretical densification and expansion of the manuscript.

Lattes: http://lattes.cnpq.br/7470127128501920.

E-mail: lucianaostetto@id.uff.br.

Responsible publisher: Lia Machado Fiuza Fialho Ad hoc experts: Michelle de Freitas Bissoli e Joceane da Silva Machado 


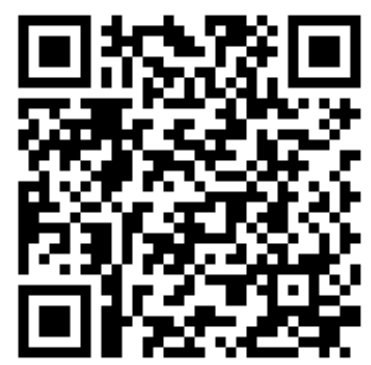

Received on September 8, 2019.

Accepted on January 29, 2020. 